\title{
The retinoblastoma gene product protects E2F-1 from degradation by the ubiquitin-proteasome pathway
}

\author{
Francesco Hofmann, ${ }^{1}$ Fabio Martelli, ${ }^{1}$ David M. Livingston, ${ }^{2}$ and Zhiyan Wang ${ }^{1}$ \\ The Division of Neoplastic Disease Mechanisms, Dana-Farber Cancer Institute and The Harvard Medical School, \\ Boston, Massachusetts 02115 USA
}

\begin{abstract}
E2F-1 plays a crucial role in the regulation of cell-cycle progression at the $G_{1}-S$ transition. In keeping with the fact that, when overproduced, it is both an oncoprotein and a potent inducer of apoptosis, its transcriptional activity is subject to multiple controls. Among them are binding by the retinoblastoma gene product ( $\mathrm{pRb}$ ), activation by cdk3, and S-phase-dependent down-regulation of DNA-binding capacity by cyclin A-dependent kinase. Here we report that E2F-1 is actively degraded by the ubiquitin-proteasome pathway. Efficient degradation depends on the availability of selected E2F-1 sequences. Unphosphorylated pRb stabilized E2F-1, protecting it from in vivo degradation. $\mathrm{pRb}$-mediated stabilization was not an indirect consequence of $G_{1}$ arrest, but rather depended on the ability of $p R b$ to interact physically with E2F-1. Thus, in addition to binding E2F-1 and transforming it into a transcriptional repressor, $\mathrm{pRb}$ has another function, protection of E2F-1 from efficient degradation during a period when $\mathrm{pRb} / \mathrm{E} 2 \mathrm{~F}$ complex formation is essential to regulating the cell cycle. In addition, there may be a specific mechanism for limiting free E2F-1 levels, failure of which could compromise cell survival and/or homeostasis.
\end{abstract}

[Key Words: E2F; pRb; cell-cycle control; ubiquitin-proteasome; protein degradation]

Received July 16, 1996; revised version accepted September 18, 1996.

E2F-1 is the first cloned member of a family of transcription factors generically referred as E2F. Five different E2F species (E2F-1, -2, -3, -4, -5) and three DP family members (DP-1, -2, -3) have been identified and characterized (for review, see Lam and La Thangue 1994; Hijmans et al. 1995; Ormondroyd et al. 1995; Sardet et al. 1995). E2Fs and DPs form heterodimers, bind to, and transactivate promoters of several genes whose products are active in cell-cycle regulation or DNA replication (for review, see Nevins 1992; De Gregori et al. 1995; Duronio and O'Farrell 1995; Ohtani et al. 1995; Schulze et al. 1995; Botz et al. 1996; Geng et al. 1996). The deregulated expression of E2F has been shown to lead to neoplastic transformation and tumor formation by E2F-1-transformed cells (Johnson et al. 1994a; Singh et al. 1994; Xu et al. 1995), and its induction in serum-deprived, quiescent cells has been reported to promote S-phase entry followed by apoptosis (Johnson et al. 1993; Qin et al. 1994; Shan and Lee 1994; Wu and Levine 1994). Moreover, recent observations derived from studies on mice homozygous for a nonfunctional E2F-1 allele suggest strongly that E2F-1 has a tumor-suppression function as well (Field et al. 1996; Weinberg 1996; Yamasaki et al. 1996). Existing

\footnotetext{
${ }^{1}$ These authors contributed equally to this work.

${ }^{2}$ Corresponding author.
}

evidence points to a role for its apoptosis-inducing activity in this regard (Field et al. 1996).

E2F-1 function as a transcription factor is tightly regulated by multiple mechanisms during the cell cycle. In $\mathrm{G}_{1}$, the product of the retinoblastoma gene, $\mathrm{pRb}$ (for review, see Weinberg 1995), binds, in its hypophosphorylated form, to E2F-1, suppressing the trans-activation potential of the transcription factor and converting it into a trans-repressor (Weintraub et al. 1992; Lam and Watson 1993; Johnson et al. 1994b; Neuman et al. 1994; Porcu et al. 1994; Adnane et al. 1995; Bremner et al. 1995; Sellers et al. 1995; Weintraub et al. 1995; Herrera et al. 1996). In late $G_{1}$ cyclin-dependent kinases phosphorylate $p R b$, leading to the dissociation of $\mathrm{pRb} / \mathrm{E} 2 \mathrm{~F}-1$ complexes. E2F1/DP complexes, which require cdk3 kinase activity to reach their maximal trans-activation potential (Hofmann and Livingston 1996), then assume full transcription stimulation function of selected genes. After peaking at $G_{1} / S$ and during early $S$ (Hsiao et al. 1994; Johnson et al. 1994b; Neuman et al. 1994), E2F-1 trans-activation activity decreases thereafter. The waning of its activity in mid- to late $S$ phase depends on the action of cyclin $\mathrm{A} / \mathrm{cdk} 2$, which binds to a selected sequence in the amino-terminal region of E2F-1, phosphorylates DP-1 that was bound to E2F-1, and down-regulates the DNAbinding capacity of the heterodimer (Krek et al. 1994).

Another level of regulation of E2F-1 function is repre- 
sented by its own cell cycle-dependent expression. In quiescent cells induced to exit from $\mathrm{G}_{0}$, E2F-1 expression, which was unmeasurable in $G_{0}$, rises as cells approach mid- to late $G_{1}$ (Kaelin et al. 1992; Shan et al. 1992; Ginsberg et al. 1994). Indeed, in a recent study, E2F-1, in human primary $T$ cells exiting $G_{0}$, was first apparent by Western blot at $G_{1} / S$ (Moberg et al. 1996). One or more E2F species, including E2F-1, can and likely do trans-activate the E2F-1 promoter during exit from $\mathrm{G}_{0}$, possibly contributing to this increase in E2F-1 synthesis (Hsiao et al. 1994; Johnson et al. 1994b; Neuman et al. 1994). By contrast, transcription of the E2F-1 gene decreases in late $S$, a phenomenon that likely depends, at least in part, upon the negative regulation of its DNAbinding capacity by cyclin A-dependent kinase. It is also clear that the abundance of E2F-1 is relatively low in multiple human cell lines (W.G. Kaelin, X. Qin, P. Adams, D.M. Livingston, and F. Hofmann, unpubl.). This raised the question of whether there were controls affecting protein abundance, such as protein stability.

Several proteins involved in cell-cycle regulation have been reported to be actively degraded at defined points during the cycle. In some cases, their degradation is necessary to ensure correct progression through the cell cycle (Nurse 1994; Wuarin and Nurse 1996). Cyclins (Glotzer et al. 1991; Amon et al. 1994; Deshaies et al. 1995; Seufert et al. 1995; Yaglom et al. 1995; Clurman et al. 1996; Lanker et al. 1996; Won and Reed 1996), cyclindependent kinase inhibitors (Schwob et al. 1994; Pagano et al. 1995), p53 (Scheffner et al. 1993), and cdc25 (Nefsky and Beach 1996) have been shown to be degraded actively by the ubiquitin-proteasome pathway (for review, see Ciechanover 1994; Hochstrasser 1995). Ubiquitin molecules are bound covalently to lysine residues of the target protein via an isopeptide bond. The linkage between ubiquitin and the target protein, as well as the ubiquitin chain elongation, are performed by the concerted action of three different enzymes, a ubiquitin-activating enzyme (E1), a ubiquitin-conjugating enzyme (E2), and a ubiquitin-protein ligase (E3) (Scheffner et al. 1995). Polyubiquitinated proteins are then recognized by the $26 \mathrm{~S}$ protease complex, referred as the proteasome, which degrades the targeted protein and releases reutilizable ubiquitin.

Here we present evidence that E2F-1 is unstable in vivo and that its instability results from its degradation by the ubiquitin-proteasome pathway. Efficient and specific degradation depends upon discrete E2F-1 sequences whose availability to the ubiquitin proteasome pathway is down-regulated by $\mathrm{pRb}$ binding. Similar observations have been obtained by M.R. Campanero and E.K. Flemington (in prep.) and G. Hateboer, R.M. Kerkhoven, R. Bernards, and R.L. Beijersbergen (in prep.).

\section{Results}

The carboxy-terminal domain of E2F-1 confers protein instability

Expression plasmids encoding E2F-1 and various mutants derivatives were transfected into U2OS cells. The mutants were defective in DNA binding (E132 and E177), stable binding of cyclin A-dependent kinase ( $\Delta 24)$, and largely (albeit not wholly) defective in pRb binding $(\Delta 18)$. Another mutant, $\Delta 5$, has sustained a five-residue deletion within the $\mathrm{pRb}$ binding domain, which only slightly impaired its ability to bind $\mathrm{pRb}$ or to trans-activate. In Western blots performed on the relevant transfected cell lysates, we noticed that none of these allelic products were readily detectable, save for E2F-1-(1-363), a deletion mutant lacking the carboxy-terminal 74 amino acids containing the trans-activation and $\mathrm{pRb}$ binding domains.

To determine whether the discrepancies in protein accumulation were attributable to differences in protein stability rather than in transfection or transcription efficiency, the protein levels reflected in a given Western blot were normalized for the corresponding mRNA present in each of the transfected cell extracts (Fig. 1A). In such a controlled analysis, it was clear that E2F-1-(1-

A

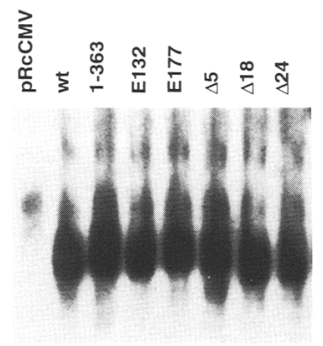

B

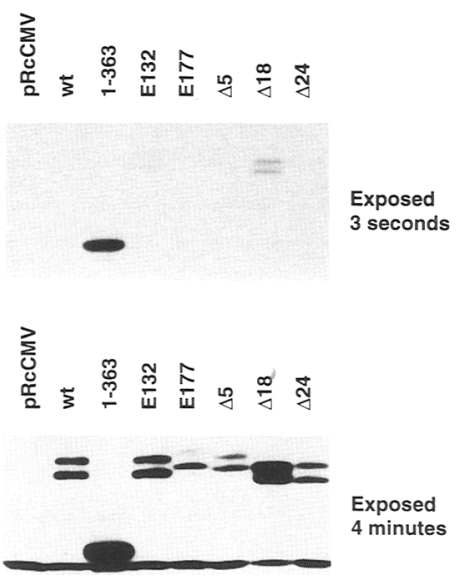

Figure 1. Accumulation of various E2F-1 species upon normalization for mRNA. Expression plasmids encoding HA-E2F-1, HA-E2F-1-(1-363), HA-E2F-1-(E132), HA-E2F-1-(E177), HA-E2F1- $\Delta 5$, HA-E2F-1- $\Delta$ 18, HA-E2F-1- $\Delta 24$ (4 $\mu$ g each), or the control vector $\mathrm{pRcCMV}$ were transfected into U2OS cells. $(A)$ Northern blot probed with E2F-1 cDNA confirming the accurancy of the normalization for equal amounts of mRNA as described in Materials and Methods. (B) Protein accumulation, normalized for mRNA, as determined by Western blot analysis using a monoclonal anti-HA antibody (12CA5). The upper panel shows the chemiluminescent signal obtained after a $3-\mathrm{sec}$ film exposure. The lower panel shows the results obtained with the same blot after a 4-min exposure. 
363) accumulated to much higher and E2F-1- $\Delta 18$ accumulated to a slightly higher level than wild-type E2F-1 or any of the other mutants tested in the experiment (Fig. 1B; cf. 3-sec and 4-min exposures). Because the protein data were normalized for mRNA abundance, the accumulation effects observed could not be ascribed to differential transcription or mRNA stability. Virtually identical differences in protein accumulation were also observed in CV1P and NIH3T3 cells (data not shown). Similarly, nontagged E2F-1 versions behaved identically with HA-tagged ones (data not shown), indicating that the accumulation behavior of the wild-type and relevant mutant species is not cell-line or HA tag-dependent.

This conclusion, in turn, raised the question of whether the differences in accumulation were a result of differential protein stability. To test this possibility, pulse-chase experiments were performed on suitably transfected cells. In agreement with the data shown in Figure 1, the wild-type protein and the mutants that accumulated to a comparably low level decayed rapidly. Indeed, the kinetics of turnover were indistinguishable among them (Fig. 2A), with the half-life of wild-type E2F-1 estimated in the 2-3 hr range (Fig. 2B). By contrast, E2F-1-(1-363), shown above to accumulate to a high level in Figure 1, was a much more stable protein (half-life $>10 \mathrm{hr}$ ) than wild-type E2F-1 (Fig. 2A,C). In this assay, the half-life of E2F-1- $\Delta 18$ was, reproducibly, only slightly higher $(<0.5 \mathrm{hr}$, see Fig. 5, below) than that of E2F-1 wild-type, in keeping with the difference in accumulation observed above. Hence, E2F-1 is fundamentally unstable, and the data imply that certain deletions in the carboxy-terminal region of the protein render it less susceptible to degradation. Moreover, E2F-1 degradation does not depend on the capacity of the protein to bind to DNA or to cyclin A-dependent kinase.

\section{$p R b$ binding stabilizes E2F-1 protein}

$\mathrm{pRb}$ binds to E2F-1, and a sequence within the carboxyterminus of the latter contributes to complex formation (Helin et al. 1992; Kaelin et al. 1992; Shan et al. 1992). Given the implication that carboxy-terminal sequences also contribute to E2F-1 stability, we asked whether pRb binding affected the stability of E2F-1. To address this question, an E2F-1 expression plasmid was transfected into U2OS cells, alone or together with a fourfold excess of an expression plasmid encoding a pRb mutant, $\mathrm{pRb} \Delta \mathrm{p} 34$, which binds E2F-1 normally, but cannot be phosphorylated in these cells, because a number of its potential phosphorylation sites have been mutated (Hamel et al. 1990). U2OS cells phosphorylate wild-type $\mathrm{pRb}$ in an uncontrolled manner attributable, at least in part, to the absence of the cdk4/6-specific inhibitor, p16 (Otterson et al. 1995). Hence, unlike wild-type pRb, the above-noted phosphosite mutant can bind stably to E2F-1 in U2OS cells.

At two different inputs of both E2F-1 and pRb $\Delta \mathrm{p} 34$, the presence of the latter led to the accumulation of higher quantities of E2F-1 (Fig. 3B), despite the presence of equivalent quantities of E2F-1 mRNA (Fig. 3A). This

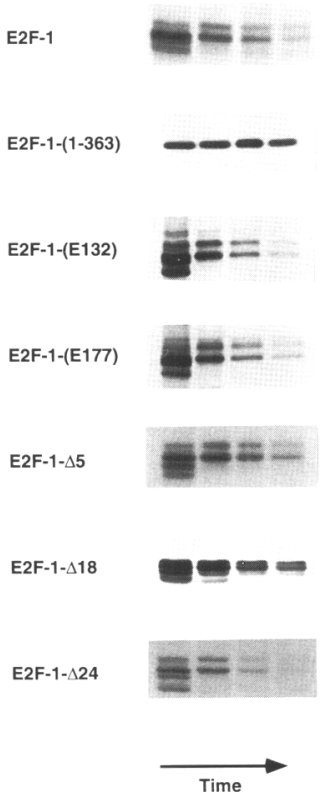

B

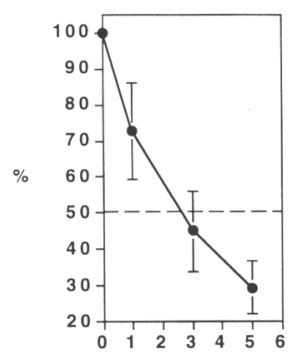

hrs

C

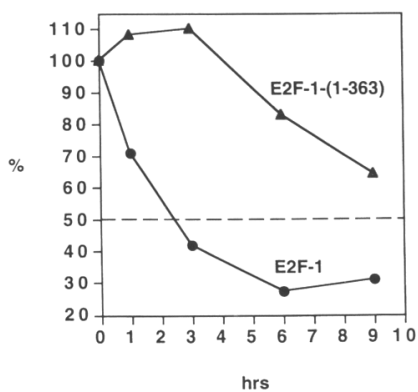

Figure 2. Accumulation of ectopically expressed E2F-1 species depends on protein stability. (A) Expression plasmids for the indicated HA-E2F-1 species $(4 \mu \mathrm{g})$ were transfected into U2OS cells. Cells were pulsed with $\left[{ }^{35} \mathrm{~S}\right]$ methionine for $30 \mathrm{~min}$ and chased for $0,1,3$, and $5 \mathrm{hr}$, followed by immunoprecipitation with the anti-HA monoclonal antibody (12CA5), as described in Materials and Methods. Autoradiography reveals the differences in protein turnover among the various E2F species tested. $(B)$ Several pulse-chase experiments for HA-E2F-1 were densitometrically traced and the data were plotted as a function of time. The E2F-1 signal detected at time $0 \mathrm{hr}$ was set to $100 \%$ and used to normalize the signal at the subsequent time points. The vertical bars represent standard deviation. $(C)$ Cells transfected with expression plasmids encoding HA-E2F-1 wild-type $(4 \mu \mathrm{g})$ or HA-E2F-1-(1-363) $(4 \mu \mathrm{g})$ were pulsed with $\left[{ }^{35} \mathrm{~S}\right] \mathrm{methio}-$ nine and chased for $0,1,3,6$ and $9 \mathrm{hr}$ to compare their decay over a longer period. The data obtained from the densitometric tracing were plotted as a function of time. The signal at time 0 $\mathrm{hr}$ was set to $100 \%$ and used as a standard for the subsequent time points.

pRb-linked increase in E2F-1 accumulation was subsequently found, in pulse-chase experiments, to correlate closely with an increase in E2F-1 protein stability (Fig. $4 \mathrm{~A}, \mathrm{Cl}$. One can ascribe the latter effect to complex formation between the $\mathrm{pRb}$-phospho mutant and a substantial portion of the overproduced E2F-1 in the transfected culture and not to a state of $G_{1}$ arrest induced by this $\mathrm{pRb}$ mutant because under the conditions of this experiment, the quantity of ectopically expressed $\mathrm{pRb}$ was not sufficient to arrest the growth of U2OS, as determined by FACScan analysis (Fig. 4D). In further support of the belief that the E2F-1 stabilization observed in the presence of $p R b \Delta p 34$ was not attributable to $G_{1}$ arrest, the cyclindependent kinase inhibitor $p 27$, which induces a $G_{1}$ block in the presence of transcriptionally active E2F-1 when both are ectopically produced in U2OS cells 
Hofmann et al.

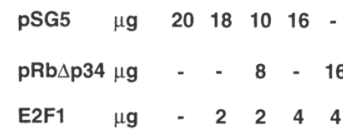

A

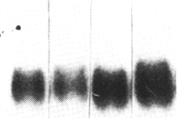

B

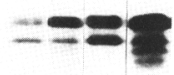

Figure 3. The presence of unphosphorylated $\mathrm{pRb}$ enhances the accumulation of E2F-1 protein upon normalization for mRNA. Total RNA was isolated and protein extracts were prepared from U2OS cells transfected, as indicated, with pSG5-E2F-1 in the presence or absence of a fourfold excess of an expression vector encoding a $\mathrm{pR} b$-phospho mutant, pCMV-Puro-HA-pRb$\Delta \mathrm{p} 34$. (A) Northern blot probed with E2F-1 cDNA confirming the accurancy of the normalization for equal amounts of mRNA as described in Materials and Methods. $(B)$ Protein accumulation, normalized for mRNA, as determined by Western blot analysis using a monoclonal anti-E2F-1 antibody (SQ41).

F. Hofmann and D.M. Livingston, unpubl.), led only to a minor E2F-1 stabilization effect (Fig. 4A,C) in cells arrested in $\mathrm{G}_{1}$ (Fig. 4D). The low-level stabilization following p 27 transfection is, most likely, a result of the binding of a small fraction of the excess quantity of ectopic E2F-1 by the less abundant endogenous, unphosphorylated $\mathrm{pRb}$ molecules.

To test whether wild-type $\mathrm{pRb}$ can stabilize E2F-1, we compared the half-life of the transcription factor in the presence and absence of wild-type $\mathrm{pRb}$ in SAOS-2 (RB - / - ) cells. Pulse-chase experiments performed with this cell line lacking $\mathrm{pRb}$ and $\mathrm{pRb}$-specific cyclin-dependent kinase activity (Ewen et al. 1993), revealed that, like $\mathrm{pRb} \Delta \mathrm{p} 34$, the presence of ectopic, unphosphorylated wild-type $\mathrm{pRb}$ led to a significant increase in the half-life of E2F-1 (Fig. 5).

To test further whether $\mathrm{pRb}$-induced stabilization was linked to pRb-E2F 1 binding, we compared the half-life of E2F-1 wild-type and of E2F-1- $\Delta 18$ in the presence and absence of $\mathrm{pRb} \Delta \mathrm{p} 34$. E2F-1- $\Delta 18$, is severely, but not completely impaired in $\mathrm{pRb}$ binding, as independently determined under the conditions used in this assay /data not shown). In keeping with this information, the same quantity of pRb $\Delta \mathrm{p} 34$ led to a twofold increase in E2F-1$\Delta 18$ half-life but to a much more substantial increase in the half-life of wild-type E2F-1 (Fig. 6). In this experiment, the concentration of $\mathrm{pRb}$ in both transfected cell lysates was virtually identical. The kinetics of wild type E2F-1 turnover in the presence of the pRb-phospho mutant were reminiscent of those of E2F-1-(1-363) (cf. Figs. 2 and 61 .

Contribution of E2F-1 carboxy-terminal sequences to its instability

The data presented above are consistent with a model in which sequences within the E2F-1 carboxyl terminus contribute to its instability and binding of unphosphorylated $\mathrm{pRb}$ to a carboxy-terminal E2F-1 sequence protects E2F-1 from degradation. In an attempt to better define the carboxy-terminal structural contribution to the observed instability, a series of E2F-1 deletion mutants were constructed (Fig. 7, see schematic representation). Given the unbroken correlation between E2F-1 stability and abundance after correction for mRNA levels, accumulation of these mutants was analyzed by Western blotting with mRNA normalization, as performed previously for both wild-type and other E2F-1 mutants (see Figs. 1 and 3). The various mutants fell into three different classes, based upon accumulation, suggesting that two distinct sequence units contribute to the instability (Fig. 7). Indeed, deletions from the carboxyl terminus to residue 417 resulted in proteins as abundant as wild type. A small but significant increase in abundance was observed for mutants bearing deletions between residues 378-408. By contrast, a major increase in abundance was noted when amino acids 363-378 were deleted.

Because E2F-1-(1-417), in keeping with prior observations (Flemington et al. 1993), was inactive in trans-activation assays (F. Martelli and D.M. Livingston, unpubl.) and was as unstable as wild type, it appears that the trans-activation domain is not required for efficient degradation. Moreover, given what was observed for E2F$1-\Delta 18$, the accumulation of those mutants lacking the pRb binding domain-E2F-1-(1-408), -(1-398), - (1-388) and $-(1-378)-$ was only slightly higher than that of wild type, indicating that the sequences dedicated to E2F-1 degradation and pRb-binding are, at least in part, distinct.

E2F-1 is degraded by the ubiquitin-proteasome pathway

Given the short half-life of E2F-1, we performed experiments aimed at identifying the proteolytic pathway responsible for its degradation. U2OS cells transfected with expression plasmids encoding HA-tagged E2F-1 wild-type or E2F-1-(1-363) were treated for $12 \mathrm{hr}$ with protease inhibitors specific for lysosomal proteases [E64 (trans-epoxysuccinyl-L-leucylamido-(4-guanidino) butane)], calpain [LLM ( $N$-acetyl-L-leucinyl-L-leucinylmethioninal)], or the proteasome LLnL ( $N$-acetyl-L-leucinyl-L-leucinyl-L-norleucinal), or with the solvent in which the inhibitors were dissolved as a control (DMSO) (Rock et al. 1994). Subsequent analysis of protein accumulation by Western blotting, using an anti-HA antibody as probe, showed that E2F-1 accumulated to significantly higher levels in cells treated with LLnL, but was unaffected by the other treatments (Fig. 8A). On the other hand, the accumulation of the more stable, HAE2F-1-(1-363) was unaffected by any of these compounds, suggesting that it is resistant to the proteasome degradation system.

These results are consistent with the proposal that E2F-1 is degraded by the ubiqutin-mediated proteosome pathway. In an effort to confirm this proposition, evidence that LLnL stabilized the wild-type protein was 
A

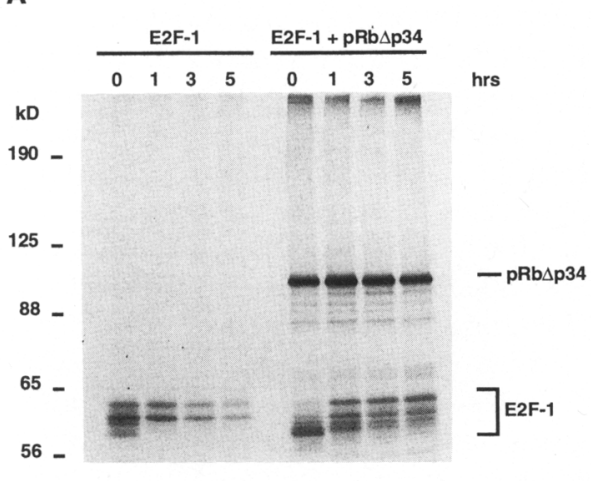

B

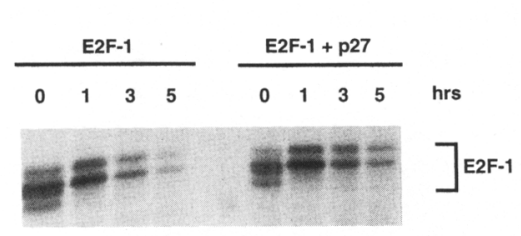

C

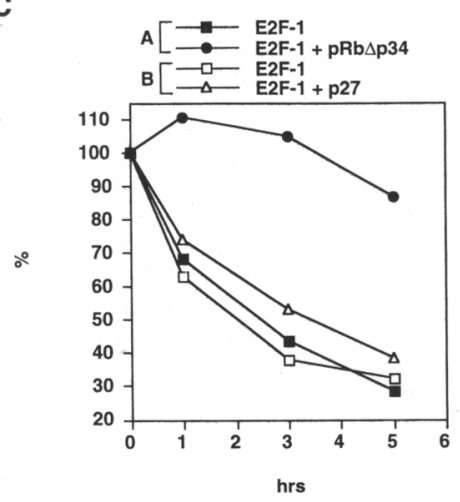

D

$\begin{array}{lccc} & \% \text { G1 } & \% \text { S } & \% \text { G2/M } \\ \text { pRcCMV } & 34.1 & 30.9 & 35.0 \\ \text { E2F-1 } & 27.5 & 38.7 & 33.8 \\ \text { E2F-1 + pRb } \Delta \text { p34 } & 23.6 & 47.0 & 29.4 \\ \text { E2F-1 } & 29.8 & 42.8 & 27.4 \\ \text { E2F-1 + p27 } & 79.9 & 11.6 & 8.5\end{array}$

Figure 4. Unphosphorylated $\mathrm{pRb}$ induces E2F-1 protein stabilization. (A) U2OS cells transfected with expression vectors for the surface marker, CD19 (pCMV-CD19, $1 \mu \mathrm{g}$ ) and wild-type HA-E2F-1 (pRcCMV-HAE2F-1, $4 \mu \mathrm{g}$ ), in the presence and absence of an expression plasmid encoding a pRb-phospho mutant (pCMV-Puro-HA$\mathrm{pRb} \Delta \mathrm{p} 34,16 \mu \mathrm{g}$ ), were pulsed with $\left[{ }^{35} \mathrm{~S}\right]-$ methionine and chased for $0,1,3$, and $5 \mathrm{hr}$, followed by immunoprecipitation with the anti-HA monoclonal antibody (12CA5) as described in Materials and Methods. $(B)$ U2OS cells cotransfected with expression vectors for the surface marker CD19 (pCMV-CD19, $1 \mu \mathrm{g}$ ), and wild-type E2F-1 (pRcCMV-HA-E2F-1, $4 \mu \mathrm{g}$ ), in the presence or absence of an expression plasmid encoding the cyclin-dependent kinase inhibitor p27, (pRcCMV-p27-HA, $5 \mu \mathrm{g}$ ), were subjected to pulse-chase analysis, as noted above. (C) The results of densitometric tracing of the data from the pulse-chase experiments shown in $A$ and $B$ were plotted as a function of time. The E2F-1 signal at time $0 \mathrm{hr}$ was set to $100 \%$. (D) Cell-cycle distribution of the CD19-containing cells, obtained by FACS analysis for each of the above-noted pulse-chase experiments and for cells transfected by vector (pRcCMV), alone, plus CD19.

then sought in pulse-chase experiments. Cells transfected with HA-tagged E2F-1 were treated with either DMSO or LLnL for $12 \mathrm{hr}$ prior to the pulse and chase periods, as well as throughout them. The results showed that the E2F-1 half-life was markedly increased in cells treated with LLnL (Fig. 8B,C).

We also performed experiments aimed at searching for ubiquitinated E2F-1 species. E2F-1 was transfected into U2OS cells in the presence of an expression plasmid encoding myc epitope-tagged ubiquitin (Ward et al. 1995). After treatment of the cells for $12 \mathrm{hr}$ with LLnL or with DMSO, denatured extracts were prepared and subjected to Western blot analysis using an anti HA-antibody to match the amount of HA-E2F-1 to be immunoprecipitated from samples treated with DMSO or LLnL (Fig. 9). Equivalent quantities of E2F-1 were immunoprecipitated with a mixture of anti-HA and anti-E2F-1 monoclonal antibodies followed by Western blot analysis using an anti-myc polyclonal antibody. Myc-immunoreactive material of high molecular weight was observed only in the combined E2F/HA immunoprecipitate derived from LLnL-treated cells cotransfected with HA-E2F-1 and myc-ubiquitin (Fig. 9). Thus, E2F-1 can be ubiquitinated and efficiently degraded by the ubiquitin-proteasome pathway, in keeping with the relatively specific stabilization effect of LLnL.

\section{Discussion}

From the results reported here, it appears that E2F-1, a powerful transcription factor that likely plays an important role in the control of $G_{1}$ exit and $S$ phase entry, is an unstable protein. Indeed, this emanates from the fact that E2F-1 is a target of the ubiquitin proteasome degradation pathway, a process now known to affect key mechanisms underlying multiple elements of cellular homeostasis, including cell-cycle control. For example, at least two regulators of $G_{1} / S$ phase passage, $p 27$ and $\mathrm{p} 40^{\text {sicl }}$, come under ubiqutin-proteasome degradation control (Schwob et al. 1994; Pagano et al. 1995), and, in the latter case, efficient degradation is essential for the initiation of DNA replication at the outset of $S$ phase (Schwob et al. 1994 and K. Nasmyth, pers. comm.). Cyclin B, cyclin E, certain yeast cyclins, and cdc25 are also short-lived cell-cycle control elements, and their degradation, too, is cell-cycle controlled and ubiquitin mediated (Glotzer et al. 1991; Amon et al. 1994; Deshaies et al. 1995; Seufert et al. 1995; Yaslom et al. 1995; Clurman et al. 1996; Lanker et al. 1996; Nefsky and Beach 1996; Won and Reed 1996).

Similar to some of the above-noted polypeptides, E2F-1 degradation appears to be governed, at least in part, by elements of its own primary structure, some of which lie within the carboxy-terminal region of the protein. Therefore, the degradation process depends upon the integrity of certain elements of E2F-1 structure, in keeping with the view that it is a specific, biologically important process. From what is apparent, one can argue that deletion of sequences extending from residues 363 to 378 greatly compromises the efficiency of E2F-1 degradation. On the other hand, although the data support the notion that neither the DNA binding domain nor the cyclin A binding unit participate in this process, one cannot eliminate a role in governing the degradation process for yet other sequences, e.g., those extending from the carboxyterminal boundary of the DNA-binding domain to resi- 
A

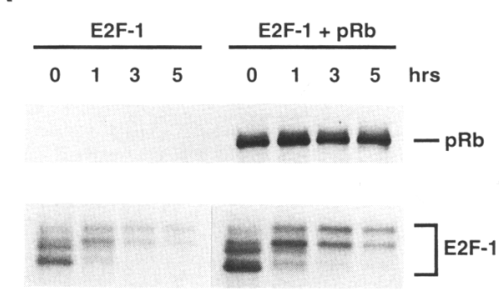

B

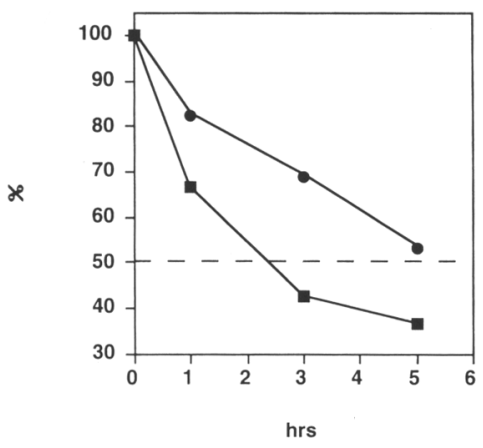

Figure 5. Wild-type $\mathrm{pRb}$ induces E2F-1 protein stabilization. (A) Pulse-chase experiments were performed in SAOS-2 cells transfected with pRcCMV-HA-E2F- $1(4 \mu \mathrm{g})$ in the presence or absence of an expression vector encoding wild-type $\mathrm{pRb}, \mathrm{pCMV}$ $\mathrm{pRb}(20 \mu \mathrm{g})$. Cells were pulsed with $\left[{ }^{35} \mathrm{~S}\right]$ methionine and chased for $0,1,3$, and $5 \mathrm{hr}$, followed by immunoprecipitation with monoclonal antibodies to the HA-tag (12CA5) or to pRb (PMG3245), as described in Materials and Methods. (B) Results of densitometric tracing of the experiment shown in $A$ were plotted as a function of time. The signal for E2F- 1 at time $0 \mathrm{hr}$ was set to $100 \%$ and used as a standard for the subsequent time points. ( $\square$ ) E2F-1; (O) E2F $1+$ pRb.

due 363 . Further genetic analysis will be required to address this question. Yet, whatever the outcome of these studies, the sequences already shown to be involved and/ or any new ones that fall into a similar category might be viewed as contributing to the presentation of E2F-1 to the ubiquitin-proteasome pathway.

$\mathrm{pRb}$ appears to serve as a significant and relatively specific inhibitor of E2F-1 degradation. Moreover, the data imply strongly that $\mathrm{pRb} / \mathrm{E} 2 \mathrm{~F}-1$ complex formation through an interaction at the carboxyl terminus of the latter is an important part of the protection process. The E2F-1- 18 mutant results (Fig. 6) support such a view. Similarly, that certain mutants were unable to transactivate in a reporter assay, but were still unstable, indicates that the E2F-1 protein domains responsible for trans-activation and degradation are, in part, distinct. Such a result implies that these two characteristics of E2F-1 are dissociable. This observation, together with the finding that E2F-1 mutants unable to bind to DNA were as unstable as wild-type E2F-1, indicate that degradation does not occur at one or more cellular promoter sites, per se. On the other hand, results of this kind do not eliminate the possibility that E2F-1 mediated gene expression events is an important part of the degradation mechanism. For example, it remains possible that endogenous E2F-1 activates (represses) certain cellular genes as part of the process that leads to E2F-1 instability. Hence, in transient transfection assays, degradation of the transfected protein may occur with the assistance of gene expressional effects of endogenous E2F-1 and/or other members of this extended transcription factor family.

How might $\mathrm{pRb}$ binding translate into E2F-1 stability? Clearly, there is not yet enough information to answer this question fully. However, there may be a parallel between $\mathrm{pRb}$ suppression of E2F-1 trans-activation function and its suppression of E2F-1 degradation. In both cases, the $\mathrm{pRb}$ binding site and the sequences that participate in trans-activation and self-degradation are vicinal to one another, suggesting some form of steric inhibition by $\mathrm{pRb}$ of the relevant E2F-1 property. Clearly, it will be possible to go beyond such an inference only when the detailed structure-function relationships underlying E2F-1 degradation are understood fully.

In our ongoing analysis of E2F-1 degradation, we observed, in a stable cell line producing ectopic E2F-1 under the control of an inducible promoter, cell cycle-dependent differences in the abundance of the protein. In these experiments, there appeared to be a sharp drop-off in intracellular E2F-1 protein levels (as measured by Western blotting) in S phase. Whether this reflects only the timing of dissolution of $\mathrm{pRb} / \mathrm{E} 2 \mathrm{~F}-1$ complexes and the subsequent degradation of free E2F-1 and/or the action of additional factors remains to be determined in cells in which wild-type E2F-1 can be detected without the use of transfection technology. The latter has been necessary to date, because of the relatively low levels of E2F-1 expression in most continuous cell lines.

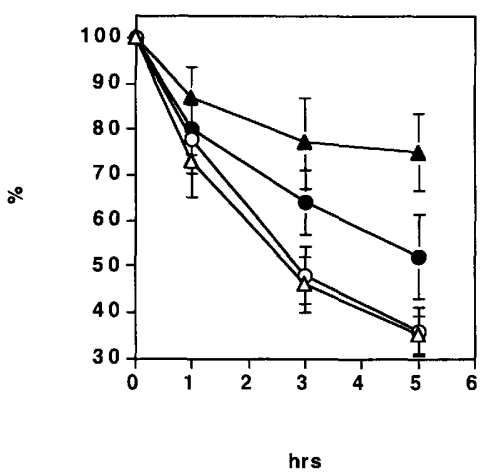

Figure 6. Unphosphorylated pRb stabilizes E2F-1 through direct binding. Pulse-chase experiments were performed on U2OS cells transfected with pRcCMV-HA-E2F-1 $(4 \mu \mathrm{g})$ (triangles) or pRcCMV-HA-E2F-1- $\Delta 18(4 \mu \mathrm{g})$ (circles) in the presence (filled symbols) or absence (open symbols) of an expression vector encoding the pRb-phospho mutant, pCMV-Puro-HA-pRb $\Delta$ p34 (16 $\mu \mathrm{g})$. Upon densitometric tracing, the results of five independent experiments were plotted as a function of time. The signal for E2F-1 or E2F-1- $\Delta 18$ at time 0 was set as $100 \%$. Vertical bars represent standard deviation. 


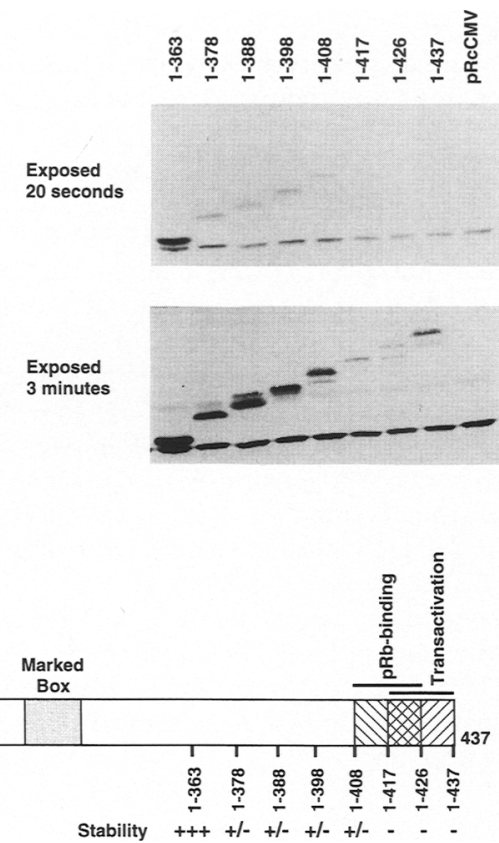

Figure 7. Contribution of E2F-1 carboxy-terminally located subdomains to protein instability. Several pRcCMV-derived expression vectors $(4 \mu \mathrm{g})$ encoding wild-type HA-E2F-1 and various carboxy-terminal truncation mutants were analyzed for accumulation upon transfection into U2OS cells. Total RNA was isolated, and cell lysates were also prepared. Upon normalization for equivalent amounts of mRNA encoding each species, ectopic E2F-1 protein accumulation was analyzed by Western blotting using an anti-HA monoclonal antibody (12CA5) as probe. An estimate of the protein stability derived from the level of accumulation of each deletion mutant and a schematic representation of the known E2F-1 functional domains are shown.

The biological significance of the $\mathrm{pRb}$-modulated and ubiquitin/proteasome-mediated degradation of E2F-1 is not yet understood. However, there are certain notable considerations.

First, E2F-1 is a potent oncogen and cell-killing element. Indeed, it plays a normal role in the latter guise, as shown by the phenotypes of mice lacking both E2F-1 alleles (Field et al. 1996). Better still, it is now clear that the higher the accumulation of E2F-1, the greater its potential for both killing and transformation (Shan and Lee 1994; G. Xu, W. Krek, and D.M. Livingston, unpubl.). One might imagine the possibility that efficient degradation of this protein contributes to normal cellular homeostasis, at least in part, through a premature deathavoidance mechanism. Alternatively, avoidance of the consequences of E2F-1 neoplastic transformation function would also be accomplished by a process that limited its abundance. In this regard, it is worth noting that most, if not all, human tumors have sustained a defect in $\mathrm{pRb}$ function or its regulation that may result in E2F being less tightly controlled by the pocket protein (Weinberg 1995). In that setting, the transcription factor could, in principle, serve a neoplastic transforming function.
Second, in at least certain settings, $\mathrm{pRb}$ must bind to one or more E2F species (E2F-1 is likely among them) and convert them into transcriptional repressors to execute its growth-suppressive function (Sellers et al. 1995; Yamasaki et al. 1996). In this context, pRb-modulation of E2F-1 degradation may assume additional importance. Specifically, $\mathrm{pRb}$ binding to E2F-1 in $\mathrm{G}_{1}$ would be expected to stabilize the latter during a phase of the cell cycle when a certain amount of $\mathrm{pRb}-\mathrm{E} 2 \mathrm{~F}-1 / \mathrm{DP}$ complex must be present for $p R b$ to express its $G_{1}$ exit control function.

Yet other timely forces that limit E2F-1 transcription function are at play during the cell cycle. For example, E2F-1 synthesis fluctuates during the cell cycle (Hsiao et al. 1994; Johnson et al. 1994b; Neuman et al. 1994), being absent prior to mid- to late $G_{1}$ in cells exiting from $\mathrm{G}_{0}$ (Kaelin et al. 1992; Shan et al. 1992; Ginsberg et al.

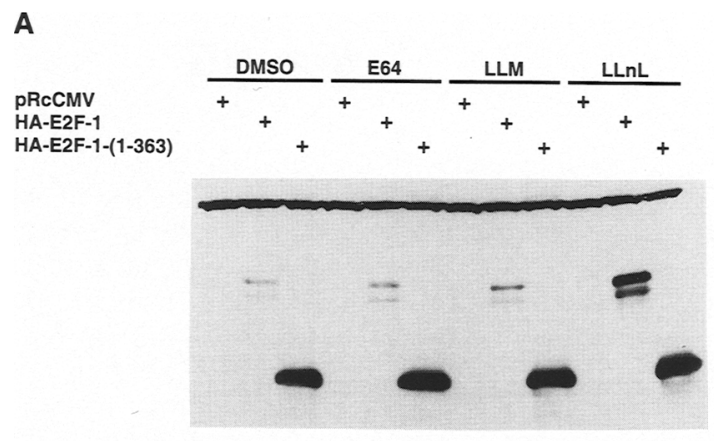

B

C

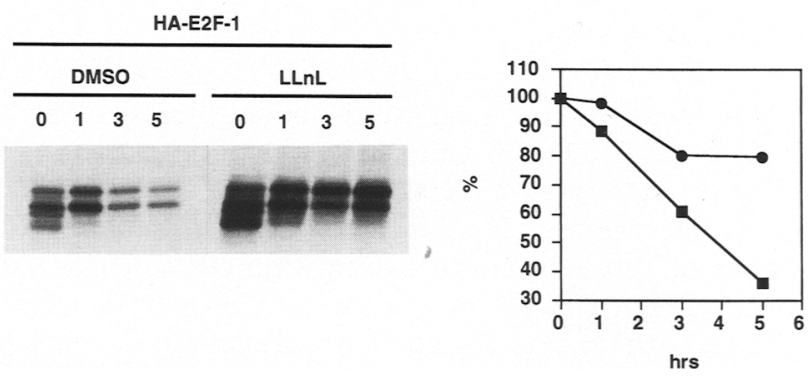

Figure 8. Inhibition of proteasome activity induces E2F-1 protein stabilization. (A) U2OS cells transfected with either pRcCMV $(4 \mu \mathrm{g})$, pRcCMV-HA-E2F-1 (4 $\mu \mathrm{g})$ or pRcCMV-HA-E2F-1(1-363) (4 $\mu \mathrm{g}$ ) were treated with either DMSO, a lysosomal protease inhibitor (E64), a calpain inhibitor (LLM), or a proteasome inhibitor (LLnL) for $12 \mathrm{hr}$, as described in Materials and Methods. Cell extracts were prepared, and protein accumulation was analyzed by Western blotting using a monoclonal antibody to the HA-tag (12CA5). (B) U2OS cells transfected with pRcCMVHA-E2F-1 $(4 \mu \mathrm{g})$ were treated with either DMSO or LLnL for 12 $\mathrm{hr}$ and pulsed-chased in the presence of either DMSO or LLnL as described in Material and Methods. $(C)$ The data obtained from densitometric tracing of the pulse-chase results shown in $B$ were plotted as a function of time. The E2F-1 signal at time $0 \mathrm{hr}$ in the presence of either DMSO $(\mathbf{\square})$ or $\operatorname{LLnL}(0)$ was set as $100 \%$. 


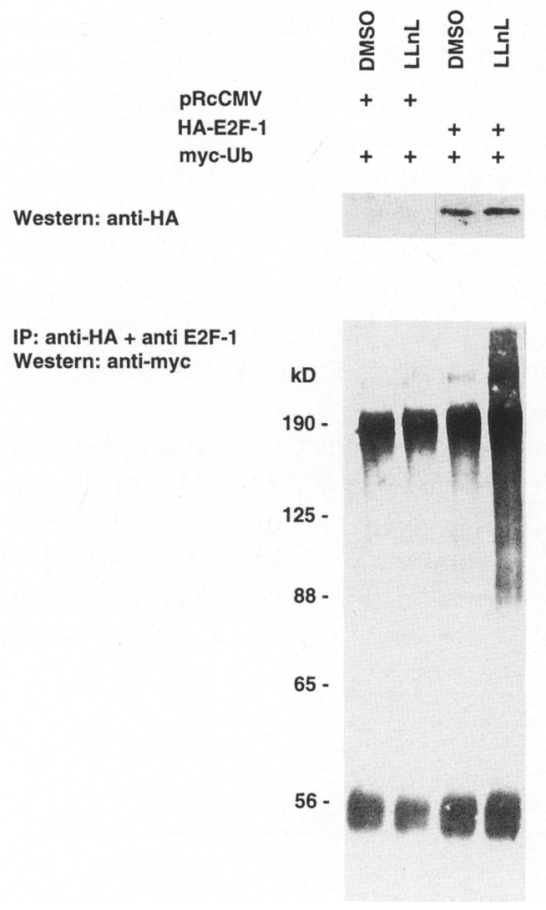

Figure 9. E2F-1 is ubiquitinated. Cell extracts, obtained from U2OS cells transfected with pRBG4-His6-myc-Ub $(20 \mu \mathrm{g})$ in the presence or absence of pRcCMV-HA-E2F-1 $(4 \mu \mathrm{g})$ and treated with either DMSO or LLnL for $15 \mathrm{hr}$, were first analyzed by Western blot using a monoclonal antibody to the HA-tag (12CA5) to be able to match up the amount of E2F-1 to be immunoprecipitated from samples treated with either DMSO or LLnL. Immunoprecipitation with a mixture of monoclonal antibodies to the HA-tag (12CA5) and to E2F-1 (SQ41) was performed, followed by Western blot analysis using an anti-myc antibody (A14). The band at $190 \mathrm{Kd}$ is a nonspecific one appearing when $12 \mathrm{CA} 5$ was used as immunoprecipitant.

1994). Moreover, cyclin A kinase, bound stably to E2F-1, inhibits E2F-1 DNA binding function in S phase through DP-1 phosphorylation (Krek et al. 1994). The latter is of particular interest, given the S-phase arrest and apoptotic effects of eliminating this cyclin A function (Krek et al. 1995). Given what is now known, it seems fair to hypothesize that E2F-1 degradation and cyclin A-dependent down-regulation of E2F-1 DNA binding capacity coexist and contribute to the modulation of E2F-1 activity beyond the $\mathrm{G}_{1}-\mathrm{S}$ transition. This view is supported by recent studies, in which, during Drosophila development, $\mathrm{S}$ phase-dependent apoptosis, reminiscent of that observed by Krek et al. (1995), appears to be linked to the presence of unphysiologically high levels of E2F-1 (Asano et al. 1996).

\section{Materials and methods}

Cell cultures, transfections and plasmids

U2OS and SAOS-2 cells were grown in Dulbecco's modified Eagle medium (DMEM) containing 10\% fetal bovine serum (FetalClone I, HyClone), at $37^{\circ} \mathrm{C}$ in a $10 \% \mathrm{CO}_{2}$-containing atmo- sphere. Cells were transfected by the calcium-phosphate method, as described (Chen and Okayama 1987). Cell-cycle analysis was performed, also as described (Hofmann and Livingston 1996).

The following plasmids were used for transfections: pRcCMV, pRcCMV-HA-E2F-1, -E2F-1- $\Delta 5$, -E2F-1- $\Delta 18$, -E2F-1- $\Delta 24$ (Krek et al. 1994). pRcCMV-HA-E2F-1-(1-363), -E2F-1-(E132), and -E2F-1-(E177) were constructed, respectively, from GAL4RBAP-1-(1-363) (Kaelin et al. 1992), pCMV-E2F-1-(E132) (Johnson et al. 1993), and pCMV-E2F-1-(E177) (Cress et al. 1993) as described (Krek et al. 1995; Xu et al. 1995). pSG5-E2F-1, pCMV-pRB (Qin et al. 1995), and pCMV-Puro-HA-pRb $\Delta$ p34 (Hofmann and Livingston 1996) were also used. pRBG4-His ${ }_{6}^{-}$ Myc-Ub (Ward et al. 1995) was a kind gift of R. Kopito (Stanford University, Stanford, CA). pCMV-CD19 was kindly provided by T. Tedder (Duke University, Durham, NC). pRcCMV-HA-E2F1$(1-378),-(1-388),-(1-398),-(1-408),-(1-417)$, and $-(1-426)$ were constructed using standard PCR protocols and verified by sequencing. pRcCMV-p27-HA was derived from pCMX-p27 (Toyoshima and Hunter 1994), a kind gift of T. Hunter (The Salk Institute, LaJolla, CA / by standard PCR protocols and verified by sequencing.

\section{Normalization procedure for protein accumulation analysis}

Twenty-four hours after transfection, cells were harvested by trypsinization and divided into two aliquots. One was used for Western blot analysis, and the other was used to extract RNA for Northern blot analysis, as described (Caruso et al. 1993). Equal amounts of total RNA were loaded on a gel, electrophoresed, transferred to a nylon membrane and hybridized with an E2F-1 cDNA probe. The integrity and quantity of RNA in each sample were checked by ethidium bromide staining of the ribosomal RNA in each lane. The relative intensity of the transfected E2F-1 mRNA bands was determined in a Betascope 603 Blot Analyzer (Betagen). E2F-1 protein level was measured by Western blotting, after normalization for the corresponding E2F-1 mRNA level determined by Northern blotting. Western blots normalized for transfected E2F-1 mRNA level were produced as follows: Quantities of cell extracts corresponding to equivalent quantities of mRNA were loaded on $8 \%$ SDSacrylamide gel and processed for Western blot analysis, as described below. The quantity of total extract protein in each lane was equalized by adding, where necessary, the appropriate quantity of untransfected U2OS cell lysate. To verify the accuracy of quantification, a second Northern blot was performed in which total RNA corresponding to the amount of cell extract used for the Western blot was analyzed. The quantity of total RNA in each lane was equalized using RNA obtained from untransfected U2OS cells lacking ectopic E2F-1 mRNA.

\section{Western blot analysis}

The accumulation of transfected gene products was monitored by Western blotting. Aliquots of cells were lysed in sample buffer and boiled for $5 \mathrm{~min}$. Proteins were separated in SDSpolyacrylamide gels and transferred to nitrocellulose by standard procedures. Monoclonal anti-HA (12CA5; Boehringer Mannheim), monoclonal anti E2F-1 (SQ41; Kaelin et al. 1992), and polyclonal rabbit anti-myc antibody (A14; Santa Cruz Biotechnologies) were used to detect the proteins of interest. Blots were developed, upon incubation with horseradish peroxidaseconjugated sheep-antimouse-IgG or donkey-antirabbit-IgG (Amersham), by enhanced chemiluminescence according to the manufacturer's instructions (Amersham). 


\section{Pulse-chase experiments and immunoprecipitations}

Twenty-four hours after removal of the transfection precipitate, monolayers in 10-cm dishes were washed twice with PBS and once with methionine-free DMEM (GIBCO) supplemented with glutamine (GIBCO) and $2 \%$ dialyzed fetal bovine serum (GIBCO). Methionine starvation proceeded for $1 \mathrm{hr}$ by incubating these cells at $37^{\circ} \mathrm{C}$ in $4 \mathrm{ml}$ of this medium. Then, $1.0 \mathrm{mCi}$ of $\left[{ }^{35} \mathrm{~S}\right]$ methionine (NEN) was added to each dish, and the dish was incubated at $37^{\circ} \mathrm{C}$. Thirty minutes later, the monolayer was washed twice with PBS and once with serum-free DMEM. Then $5 \mathrm{ml}$ of DMEM, supplemented with $10 \%$ fetal bovine serum (FetalClone I, HyClone) and $3 \mathrm{mg} / \mathrm{ml}$ methionine (Sigma), were added to each dish, and incubation at $37^{\circ} \mathrm{C}$ was continued for the indicated times. Cells were harvested by trypsinization, washed with PBS, resuspended in $100 \mu 1$ of $50 \mathrm{mM}$ Tris- $\mathrm{HCl} / \mathrm{pH}$ $7.5 \mid, 1 \%$ SDS, and $5 \mathrm{~mm}$ DTT and boiled. The extracts were centrifuged for $5 \mathrm{~min}$ at $12,000 \mathrm{~g}$, and the clarified supernatants were diluted with $1.4 \mathrm{ml}$ TNN buffer $(50 \mathrm{~mm}$ Tris- $\mathrm{HCl}$ at $\mathrm{pH}$ 7.4, $250 \mathrm{~mm} \mathrm{NaCl}, 5 \mathrm{~mm}$ EDTA, 0.5\% NP-40, $50 \mathrm{~mm} \mathrm{NaF}, 0.2$ mM sodium ortho-vanadate, $1 \mathrm{mM}$ DTT, $1 \mathrm{~mm}$ PMSF, and 20 $\mu \mathrm{g} / \mathrm{ml}$ aprotinin), precleared with protein $\mathrm{A}$, and immunoprecipitated with the indicated antibodies, as described previously (Hofmann and Livingston 1996). The intensity of the bands corresponding to the transfected HA-E2F-1 species was determined using a Betascope 603 Blot Analyzer (Betagen). For immunoprecipitations followed by Western blotting, protein $G$ was substituted for protein $\mathrm{A}$, both in the preclearing and immunoprecipitation steps.

\section{Proteolysis inhibitor treatment of transfected cells}

U2OS cells were exposed for 12-15 hr to the proteasome inhibitor LLnL (Sigma), the lysosomal protease inhibitor E64 (Sigma), or the calpain inhibitor LLM (Sigma), at a final concentration of $50 \mu \mathrm{M}$ (Rock et al. 1994). Each of these compounds was dissolved in DMSO, and the final concentration of DMSO in the tissue culture medium, after addition of the relevant compound, was $0.25 \%$. Hence, a culture containing $0.25 \%$ DMSO in the medium served as a concurrent control for those exposed to the above-noted compounds.

\section{Acknowledgments}

We wish to thank our divisional colleagues for their critical analysis of this work. We are grateful to Drs. T. Hunter, R. Kopito, and T. Tedder for the kind gift of expression plasmids. This work was supported by funds provided to D.M.L. by the National Cancer Institute and the Dana-Farber/Sandoz Drug Discovery Program, and to F.H. by the Swiss National Science Foundation, F.M. by the Human Frontier Science Program Organization, and Z.W. by the Cancer Research Fund of the Damon Runyon-Walter Winchell Foundation (fellowship DRG1334).

The publication costs of this article were defrayed in part by payment of page charges. This article must therefore be hereby marked "advertisement" in accordance with 18 USC section 1734 solely to indicate this fact.

\section{References}

Adnane, J., Z. Shao, and P.D. Robbins. 1995. The retinoblastoma susceptibility gene product represses transcription when directly bound to the promoter. I. Biol. Chem. 270: 88378843.

Amon, A., S. Imiger, and K. Nasmyth. 1994. Closing the cell cycle circle in yeast: G2 cyclin proteolysis initiated at mitosis persists until the activation of Gl cyclins in the next cycle. Cell 77: 1037-1050.

Asano, M., J.R. Nevins, and R.P. Wharton. 1996. Ectopic E2F expression induces S-phase and apoptosis in Drosophila imaginal discs. Genes \& Dev. 10: 1422-1432.

Botz, J., K. Zerfass-Thome, D. Spitkovsky, H. Delius, B. Vogt, M. Eilers, A. Hatzigeorgiou, and P. Jansen-Dürr. 1996. Cell cycle regulation of the murine cyclin $\mathrm{E}$ gene depends on an E2F binding site in the promoter. Mol. Cell. Biol. 16: 34013409.

Bremner, R., B.L. Cohen, M. Sopta, P.A. Hamel, C.J. Ingles, B.L. Gallie, and R.A. Phillips. 1995. Direct transcriptional repression by $\mathrm{pRb}$ and its reversal by specific cyclins. Mol. Cell Biol. 15: 3256-3265.

Caruso M., F. Martelli, A. Giordano, and A. Felsani. 1993. Regulation of MyoD gene transcription and protein function by the transforming domains of the adenovirus E1A oncoprotein. Oncogene 8: 267-278.

Chen, C. and H. Okayama. 1987. High-efficiency transformation of mammalian cells by plasmid DNA. Mol. Cell. Biol. 7: 2745-2752.

Ciechanover, A. 1994. The ubiquitin-proteasome proteolytic pathway. Cell 79: 13-21.

Clurman, B.E., R.J. Sheaff, K. Thress, M. Groudine and J.M. Roberts. 1996. Turnover of cyclin E by the ubiquitin-proteasome pathway is regulated by cdk 2 binding and cyclin phosphorylation. Genes \& Dev. 10: 1979-1990.

Cress, W.D., D.G. Johnson, and J.R. Nevins. 1993. A genetic analysis of the E2F-1 gene distinguishes regulation by $\mathrm{pRb}$, p107 and adenovirus E4. Mol. Cell. Biol. 13: 6314-6325.

De Gregori J., T. Kowalik, and J.R. Nevins. 1995. Cellular targets for activation by the E2F-1 transcription factor include DNA Synthesis- and G1/S-regulatory genes. Mol. Cell. Biol. 15: 4215-4224.

Deshaies, R.J., V. Chau and M.W. Kirschner. 1995. Ubiquitination of the $\mathrm{G}_{1}$ cyclin Cln2p by a Cdc34p-dependent pathway. EMBO I. 14: 303-312.

Duronio, R.J. and P.H. O'Farrell. 1995. Developmental control of the $G_{1}$ to $S$ transition in Drosophila: Cyclin $E$ is a limiting downstream target of E2F. Genes \& Dev. 9: 1456-1468.

Ewen, M.E., H.K. Sluss, C.J. Sherr, H. Matsushime, J. Kato, and D.M. Livingston. 1993. Functional interactions of the retinoblastoma protein with mammalian D-type cyclins. Cell 73: 487-497.

Field, S.J., F.-Y. Tsai, F. Kuo, A.M. Zubiaga, W.G. Kaelin, D.M. Livingston, S.H. Orkin, and M.E. Greenberg. 1996. E2F-1 functions in mice to promote apoptosis and suppress proliferation. Cell 85: 549-561.

Flemington, E.K., S.H. Speck, and W.G. Kaelin. 1993. E2F-1mediated transactivation is inhibited by complex formation with the retinoblastoma susceptibility gene product. Proc. Natl. Acad. Sci. 90: 6914-6918.

Geng, Y., N. Eaton, M. Picon, J.M. Roberts, A.S. Lundberg, A. Gifford, C. Sardet, and R.A. Weinberg. 1996. Regulation of cyclin E transcription by E2Fs and retinoblastoma protein. Oncogene 12: 1173-1180

Ginsberg, D., G. Vairo, T. Chittenden, Z.-X. Xiao, G. Xu, K.L. Wydmer, J.A. DeCaprio, J.B. Lawrence, and D.M. Livingston. 1994. E2F-4, a new member of the E2F transcription factor family, interacts with p107. Genes \& Dev. 8: 2665-2679.

Glotzer, M., A.W. Murray, and M.W. Kirschner. 1991. Cyclin is degraded by the ubiquitin pathway. Nature 349: 132-138.

Hamel, P.A., B.L. Cohen, L.M. Sorce, B.L. Gallie, and R.A. Phillips. 1990. Hyperphosphorylation of the retinoblastoma gene product is determined by domains outside the Simian vinus 
40 large T antigen-binding region. Mol. Cell Biol. 10: 65866595.

Helin, K., J.A. Lees, M. Vidal, N. Dyson, E. Harlow, and A. Fattaey. 1992. A cDNA encoding a pRb-binding protein with properties of the transcription factor E2F. Cell 70: 337-350.

Herrera, R., V.P. Sah, B.O. Williams, T.P. Mäkelä, R.A. Weinberg, and T. Jacks. 1996. Altered cell cycle kinetics, gene expression, and G1 restriction point regulation in $\mathrm{Rb}$-deficient fibroblast. Mol. Cell. Biol. 16: 2402-2407.

Hijmans, E.M., P.M. Voorhoeve, R.L. Beijersbergen, L.J. van't Veer, and R. Bernards. 1995. E2F-5, a new E2F family member that interacts with p130 in vivo. Mol. Cell. Biol. 15: 3082-3089.

Hochstrasser, M. 1995. Ubiquitin, proteasomes, and the regulation of intracellular protein degradation. Curr. Opin. Cell Biol. 7: 215-223.

Hofmann, F. and D.M Livingston. 1996. Differential effects of $\mathrm{cdk} 2$ and $\mathrm{cdk} 3$ on the control of $\mathrm{pRb}$ and E2F function during $\mathrm{G}_{1}$ exit. Genes \& Dev. 10: 851-861.

Hsiao, K.-M., S.L. McMahon, and P.J. Farnham. 1994. Multiple DNA elements are required for the growth regulation of the mouse E2F-1 promoter. Genes \& Dev. 8: 1526-1537.

Johnson, D.G., J.K. Schwarz, W.D. Cress, and J.R. Nevins. 1993. Expression of E2F-1 induces quiescent cells to enter S-phase. Nature 365: 349-352.

Johnson, D.G., W. Cress, L. Jakoi, and J.R. Nevins. 1994a. Oncogenic capacity of the E2F-1 gene. Proc. Natl. Acad. Sci. 91: $12823-12827$.

Johnson, D.G., K. Ohtani, and J.R. Nevins. 1994b. Autoregulatory control of E2F-1 expression in response to positive and negative regulators of cell cycle progression. Genes \& Dev. 8: $1514-1525$.

Kaelin, W.G. Jr., W. Krek, W.R. Sellers, J.A. DeCaprio, F. Ajchenbaum, C.S. Fuchs, T. Chittenden, Y. Li, P.J. Farnham, M.A. Blanar, D.M. Livingston, and E.K. Flemington. 1992. Expression cloning of a cDNA encoding a retinoblastomabinding protein with E2F-like properties. Cell 70: 351-364.

Krek, W., M.E. Ewen, S. Shirodkar, Z. Arany, W.G. Kaelin, and D.M. Livingston. 1994. Negative regulation of the growthpromoting transcription factor E2F-1 by a stably bound cyclin A-dependent protein kinase. Cell 78: 161-172.

Krek, W., G. Xu, and D.M. Livingston. 1995. Cyclin A kinase regulation of E2F-1 DNA binding function underlies suppression of an S phase checkpoint. Cell 83: 1149-1158.

Lam, E.W.-F. and N.B. La Thangue. 1994. DP and E2F proteins: Coordinating transcription with cell cycle progression. Curr. Opin. Cell Biol. 6: 859-866.

Lam, E.W.-F. and R.J. Watson. 1993. An E2F-binding site mediates cell cycle regulated repression of mouse b-myb transcription. $E M B O$ J. 12: 2705-2752.

Lanker, S., M.H. Valdivieso, and C. Wittenberg. 1996. Rapid degradation of the $\mathrm{G} 1$ cyclin $\mathrm{Cln} 2$ induced by cdk-dependent phosphorylation. Science 271: 1597-1600.

Moberg, K., M.A. Starz, and J.A. Lees. 1996. E2F-4 switches from p130 to p107 and pRb in response to cell cycle reentry. Mol. Cell. Biol. 16: 1436-1449.

Nefsky, B. and D. Beach. 1996. Publ acts as an E6-AP-like protein ubiquitin ligase in the degradation of $\operatorname{cdc} 25$. EMBO $J$. 15: $1301-1312$.

Neuman, E., E.K. Flemington, W.R. Sellers, and W.G. Kaelin. 1994. Transcription of the E2F-1 gene is rendered cell cycle dependent by E2F DNA-binding sites within its promoter. Mol. Cell. Biol. 14: 6607-6615.

Nevins, J.R. 1992. A link between the Rb tumor suppressor protein and viral oncoproteins. Science 258: 424-429.

Nurse, P. 1994. Ordering S phase and M phase in the cell cycle.
Cell 79: 547-550.

Ohtani, K., J. De Gregori, and J.R. Nevins. 1995. Regulation of the cyclin E gene by transcription factor E2F-1. Proc. Natl. Acad. Sci. 92: 12146-12150.

Ormondroyd, E., S. de la Luna, and N.B. La Thangue. 1995. A new member of the DP family, DP-3, with distinct protein products suggests a regulatory role for alternative splicing in the cell cycle transcription factor DRTF1/E2F. Oncogene 11: $1437-1446$

Otterson, G.A., S.N. Khleif, W. Chen, A. Coxon, and F.J. Kaye. 1995. CDK2N gene silencing in lung cancer by DNA hypermethylation and kinetics of p16INK4 protein induction by 5-aza-2'-deoxycytidine. Oncogene 11: 1211-1216.

Pagano, M., S.W. Tam, A.M. Theodoras, P. Beer-Romero, G. Dal Sal, V. Chau, P.R. Yew, G.F. Draetta, and M. Rolfe. 1995. Role of the Ubiquitin-proteosome pathway in regulating abundance of the cyclin-dependent kinase inhibitor p27. Science 269: 682-685.

Porcu, P., X. Grana, S. Li, J. Swantek, A. De Luca, A. Giordano, and R. Baserga. 1994. An E2F binding sequence negatively regulates the response of the insulin-like growth factor 1 (IGF-I) promoter to simian virus $40 \mathrm{~T}$ antigen and to serum. Oncogene 9: 2125-2134.

Qin, X.Q., D.M. Livingston, W.G. Kaelin, and P. Adams. 1994. Deregulated E2F-1 expression leads to $S$-phase entry and p53-mediated apoptosis. Proc. Natl. Acad. Sci. 91: 1091810922.

Qin, X.Q., D.M. Livingston, D.M. Ewen, W.R. Sellers, Z. Arany, and W.G. Kaelin. 1995. The transcription factor E2F-1 is a downstream target of RB action. Mol. Cell. Biol. 15: 742755.

Rock, K.L., C. Gramm, L. Rothstein, K. Clark, R. Stein, L. Dick, D. Hwang, and A.L. Goldberg. 1994. Inhibitors of the proteasome block the degradation of most cell proteins and the generation of peptides presented on MHC class I molecules. Cell 78: 761-777.

Sardet, C., M. Vidal, D. Cobrinik, Y. Geng, C. Onufryk, A. Chen, and R.A. Weinberg. 1995. E2F-4 and E2F-5, two members of the E2F family, are expressed in the early phase of the cell cycle. Proc. Natl. Acad. Sci. 92: 2403-2407.

Scheffner, M., J.M. Huigregste, R.D. Vierstra, and P.M. Howley. 1993. The HPV E6 and E6-AP complex functions as a ubiquitin-protein ligase in the ubiquitination of p53. Cell 75: 495-505.

Scheffner, M., U. Nuber, and J.M. Huibregste. 1995. Protein ubiquitination involving an E1-E2-E3 enzyme ubiquitin thioester cascade. Nature 373: 81-83.

Schulze, A., K. Zerfass, D. Spitovsky, J. Berges, S. Middendrop, P.Jansen-Dürr, and B. Henglein. 1995. Cell cycle regulation of cyclin A gene transcription by a variant E2F binding site. Proc. Natl. Acad. Sci. 92: 11264-11268.

Schwob, E., T. Böhm, M.D. Mendenhall, and K. Nasmyth. 1994. The B-type cyclin kinase inhibitor $\mathrm{p} 40^{\mathrm{SICl}}$ controls the $\mathrm{G}_{1}$ to $S$ transition in S. cerevisiae. Cell 79: 233-244.

Sellers, W.R., J.W. Rodgers, and W.G. Kaelin. 1995. A potent transrepression domain in the retinoblastoma protein induces a cell cycle arrest when bound to E2F sites. Proc. Natl. Acad. Sci. 92: 11544-11548.

Seufert, W., B. Futcher, and S. Jentsch. 1995. A ubiquitin-conjugating enzyme involved in the degradation of both $S$ - and M-phase cyclins. Nature 373: 78-81.

Singh, P., S. Wong, and W. Hong. 1994. Overexpression of E2F-1 in rat embryo fibroblasts leads to neoplastic transformation. EMBO I. 13: 3329-3338.

Shan, B. and W.-H. Lee. 1994. Deregulated expression of E2F-1 induces S-phase entry and leads to apoptosis. Mol. Cell. Biol. 
14: 8166-8173.

Shan, B., X. Zhu, P.-L. Chen, T. Durfee, Y. Yang, D. Sharp, and W.-H. Lee. 1992. Molecular cloning of cellular genes encoding retinoblastoma-associated proteins: Identification of a gene with properties of the transcription factor E2F. Mol. Cell. Biol. 13: 5620-5631.

Toyoshima, H. and T. Hunter. 1994. p27, a novel inhibitor of G1 cyclin-cdk protein kinase activity, is related to p21. Cell 78: 67-74.

Ward, C.L., S. Omura, and R.R. Kopito. 1995. Degradation of CFTR by the ubiquitin-proteasome pathway. Cell 83: 121127.

Weinberg, R.A. 1995. The retinoblastoma protein and cell cycle control. Cell 81: 323-330.

Weinberg, R.A. 1996. E2F and cell proliferation: A world turned upside down. Cell 85: 457-459.

Weintraub, S.J., C.A. Prater, and D.C. Dean. 1992. Retinoblastoma protein switches the E2F site from positive to negative element. Nature 358: 259-261.

Weintraub, S.J., K.N.B. Chow, R.X. Luo, S. Zhang, S. He, and D.C. Dean. 1995. Mechanisms of active transcriptional repression by the retinoblastoma protein. Nature 375: 812 815.

Won, K.-A. and S.I. Reed. 1996. Activation of cyclin E/cdk2 is coupled to site-specific autophosphorylation and ubiquitindependent degradation of cyclin E. EMBO J. 15: 4182-4193.

$\mathrm{Wu}, \mathrm{X}$. and A.J. Levine. 1994. p53 and E2F-1 cooperate to mediate apoptosis. Proc. Natl. Acad. Sci. 91: 3602-3606.

Wuarin, J. and P. Nurse. 1996. Regulating S-phase: CDKs, licensing and proteolysis. Cell 85: 785-787.

Xu, G., D.M. Livingston, and W. Krek. 1995. Multiple members of the E2F transcription factor family are the products of oncogenes. Proc. Natl. Acad. Sci. 92: 1357-1361.

Yaglom, J., H.K. Linskens, S. Sadis, D.M. Rubin, B. Futcher, and D. Finley. 1995. p34 ${ }^{\mathrm{Cdc} 28}$-mediated control of $\mathrm{Cln} 3$ cyclin degradation. Mol. Cell. Biol. 15: 731-741.

Yamasaki, L., T. Jacks, R. Bromson, E. Goillot, E. Harlow, and N.J. Dyson. 1996. Tumor induction and tissue atrophy in mice lacking E2F-1. Cell 85: 537-548. 


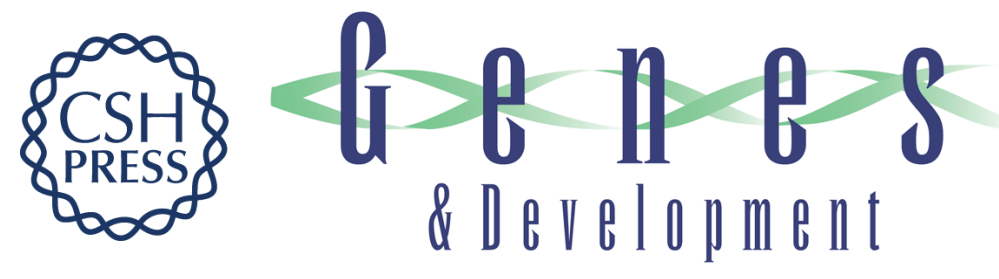

\section{The retinoblastoma gene product protects E2F-1 from degradation by the ubiquitin-proteasome pathway.}

F Hofmann, F Martelli, D M Livingston, et al.

Genes Dev. 1996, 10:

Access the most recent version at doi:10.1101/gad.10.23.2949

References This article cites 70 articles, 33 of which can be accessed free at:

http://genesdev.cshlp.org/content/10/23/2949.full.html\#ref-list-1

License

Email Alerting

Service

Receive free email alerts when new articles cite this article - sign up in the box at the top right corner of the article or click here.

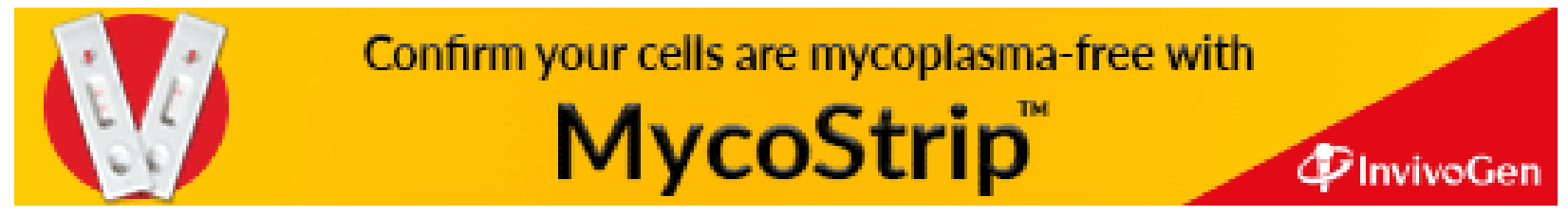

